Journal of the Society for the Study of Architecture in Canada Le Journal de la Société pour l'étude de l'architecture au Canada

\title{
Requiem for All Saints, Granville Centre
}

\section{Peter Coffman}

Volume 43, numéro 1, 2018

Religious Architecture in Canada

URI : https://id.erudit.org/iderudit/1049404ar

DOI : https://doi.org/10.7202/1049404ar

Aller au sommaire du numéro

Éditeur(s)

SSAC-SEAC

ISSN

2563-8696 (numérique)

Découvrir la revue

Citer cet article

Coffman, P. (2018). Requiem for All Saints, Granville Centre. Journal of the Society for the Study of Architecture in Canada / Le Journal de la Société pour l'étude de l'architecture au Canada, 43(1), 7-16.

https://doi.org/10.7202/1049404ar d'utilisation que vous pouvez consulter en ligne. 


\section{REQUIEM FOR ALL SAINTS, GRANVILLE CENTRE ${ }^{1}$}

PETER COFFMAN is an associate professor

in Carleton University's history and theory of

architecture program, and past president of the

Society for the Study of Architecture in Canada.

\author{
$>$ PETER COFFMAN
}

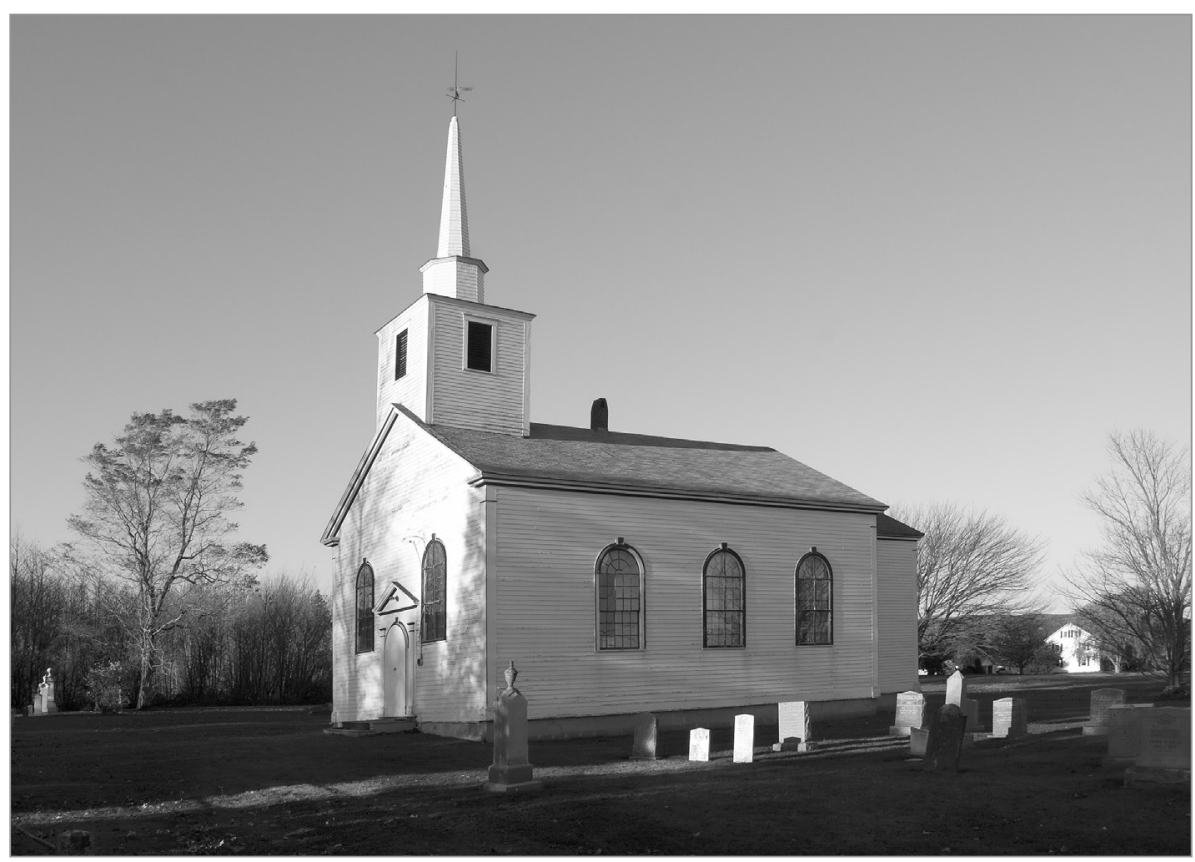

FIG. 1. ALL SAINTS, GRANVILLE CENTRE, NS, IN 2008. | PETER COFFMAN.
Eor just under two hundred years, the - church of All Saints, Granville Centre (figs. 1 and 12), stood approximately eight kilometres from the historic town of Annapolis Royal, Nova Scotia. It was founded by the first colonial bishop in the history of the Anglican Church, Charles Inglis. ${ }^{2}$ It was a visible marker of the Anglican and Loyalist identity that did much to shape the history of the Annapolis Valley. It was a manifestation of the architectural principles of the celebrated and enormously influential Scottish architect James Gibbs, integrated with the artisanship, materials, economics, and politics of early nineteenth-century Nova Scotia. ${ }^{3}$ It was a vivid three-dimensional historic document bearing witness to the presence and impact of the United Empire Loyalists in British North America. ${ }^{4}$

In 2009, All Saints was dismantled and put into storage. ${ }^{5}$ It passed its twohundredth birthday in pieces in a Nova Scotian Warehouse, before being shipped to 22380 Main Street, Abita Springs, Louisiana, where it now serves as that community's Baptist church.

The shifting identities of All Saints raise some interesting questions. Given its pre-Confederation origins, was it really a "Canadian" church? Is it now an "American" one, simply by virtue of the fact that it is now located in the United States? And how was history used, abused, or ignored when it was sold? In order to explore these questions, a brief outline of the building's history and historical context is in order. 


\section{THE HISTORY OF ALL SAINTS}

The Annapolis Valley, a fertile and picturesque region of Nova Scotia stretching roughly from Digby to Wolfville, has a complex history. It was originally Mi'kmaq territory, although the lack of built remains of that nation makes it regrettably easy to neglect that fact. The French arrived to stay (or at least that was the intention) in 1605, constructing the Habitation that was re-built as a heritage project on or near its original site in the mid-twentieth century. ${ }^{6}$ This initiated a wave of French settlement that transformed the landscape. An ingenious system of dykes and one-way sluices drained what had amounted to a swamp, making the region into what it remains today: the most productive farmland in the province. It became not only habitable, but, relatively speaking, prosperous. The Valley became the heartland of Acadie, some of whose built heritage survives in Annapolis Royal. ${ }^{7}$ The triumph of the Acadians was, however, short-lived.

In an event that has come to be known as the Grand Dérangement (commemorated today at the National Historic Site at Grand-Pré), the Acadians were brutally expelled in 1755 after Governor Charles Lawrence decided that their support in the event of conflict with France could not be relied upon. Over time some returned, and formed Acadian communities with a remarkable and distinctive architecture in towns such as Pointe-deI'Église, Saint-Bernard, and Saulnierville, in nearby Clare Municipality. ${ }^{8}$ The story of the early twentieth-century Acadian resurgence is a remarkable one, but for the purposes of this paper the most relevant consequence of the Dérangement was to make the most fertile farmland in Nova Scotia available to United Empire Loyalists.
One of the most important figures in the Loyalist resettlement of the Annapolis Valley was the Anglican Bishop of Nova Scotia, Charles Inglis [1734-1816]. An Irishborn clergyman in the Church of England, Inglis spent most of his early career in New York. He remained there after the American Revolution, although being a public figure in the new republic who displayed fierce loyalty to the English King, Country, and Established Church soon (unsurprisingly) became untenable. He returned to England in 1783, where he apparently sought a tangible reward for his record of loyalty in the face of extreme adversity. That reward came, rather spectacularly, with his appointment as Bishop of Nova Scotia in 1787, making him the first colonial bishop in the history of the Church of England and the British Empire. Once ensconced in Halifax, Inglis undertook one of the most notable churchbuilding campaigns that Canada would ever see.

That campaign had an especially great impact on the Annapolis Valley, which, as fertile land that was largely empty, became prime bait for luring Loyalists out of the United States and back into British North America. Inglis made sure that the Valley not only filled with Loyalists, but with churches that would remind everyone who saw them of the one and only Church (as he saw it) that was woven into the history and identity of the nation that had inspired their loyalty: the Church of England. At that time, the Established Church had a distinctive and unmistakable architectural identity, based on the churches (and perhaps more importantly, the pattern book) of architect James Gibbs [1682-1754]. In particular, his church of St. Martin-in-the-Fields in London (1721-1726) became what Sir John Summerson called "the type of the Anglican parish church wherever in the world English was spoken and Anglican worship upheld"9 (fig. 2). It is precisely this kind of church-essentially a classical temple with a tower and spire-that began to proliferate in the Annapolis Valley during Charles Inglis's episcopate. ${ }^{10}$ All Saints in Granville Centre was one of the younger siblings in this family. It was begun around 1811, largely completed by 1814 , and consecrated in 1826 . Vestry minutes from 1822, which list the pew rentals, make it clear that it had been in use for some time by the time of its consecration."11

\section{A CANADIAN CHURCH?}

All Saints' position as a pre-Confederation Loyalist church immediately raises some questions about how it should be interpreted. Could this church be considered "Canadian," and if so, what does that actually mean? It is perhaps easier to be clear about what it does not mean: the search for a signature "Canadian" architectural style along the lines of what Alan Gowans proposed in the 1960s has long been abandoned and will not be resumed. ${ }^{12}$ The notion that a single architectural paradigm and narrative could somehow encapsulate the experiences and values of a complex and diverse community of communities has not worn well in the time between the nation's centennial and sesquicentennial celebrations. Even if that were not the case, it would be problematic to claim iconic "Canadian" status for a building that was begun more than half a century before Confederation, in a province that would not even be a member of the initial pre-Confederation conflation of the Canada East and Canada West into the United Province of Canada. What we now know as "Canada" was not even an idea when Inglis began urging the Parish of Granville to build this church.

A more defensible claim is that any building that responds directly to the historical 
and geographical circumstances in which it is created can be considered to belong, in a genuinely meaningful way, to its place. And if that place is now part of Canada, it can be considered "Canadian" architecture. So, while there may be no such thing as "a Canadian architecture," there is a great deal of "Canadian architecture."

All Saints fits that description perfectly. It is a vivid statement of its place and time: an Anglican, Loyalist church built in British North America when the American Revolution was still very much within living memory. Its architectural ancestry is traced through John Summerson's "type of the Anglican parish church"-London's St. Martin-in-theFields, by James Gibbs.

While the difference in scale, materials, and decorative complexity hardly need pointing out, they serve to highlight All Saints' rootedness in its particular place. It embodies Gibbsian classicism, with all of its encoded "Englishness," but it is executed by carpenters of the Annapolis Valley. Somewhat paradoxically, it is an unmistakably English building, that could only have been built in Nova Scotia.

It is important to emphasize the Loyalist roots of this building campaign. To Inglis, loyalty to King and to Established Church were two sides of the same coin. In his view, encouraging religious dissentin other words, denominations such as Baptists and Methodists-was the first step on the road that ultimately led to republicanism. He saw revolution and religious dissent as part of a continuum that had to be vigorously resisted. It is therefore not surprising that the first church of Inglis's building campaign, the long-demolished Trinity Church in Digby, was explicitly a Loyalist project. Its founders appealed to Inglis for help

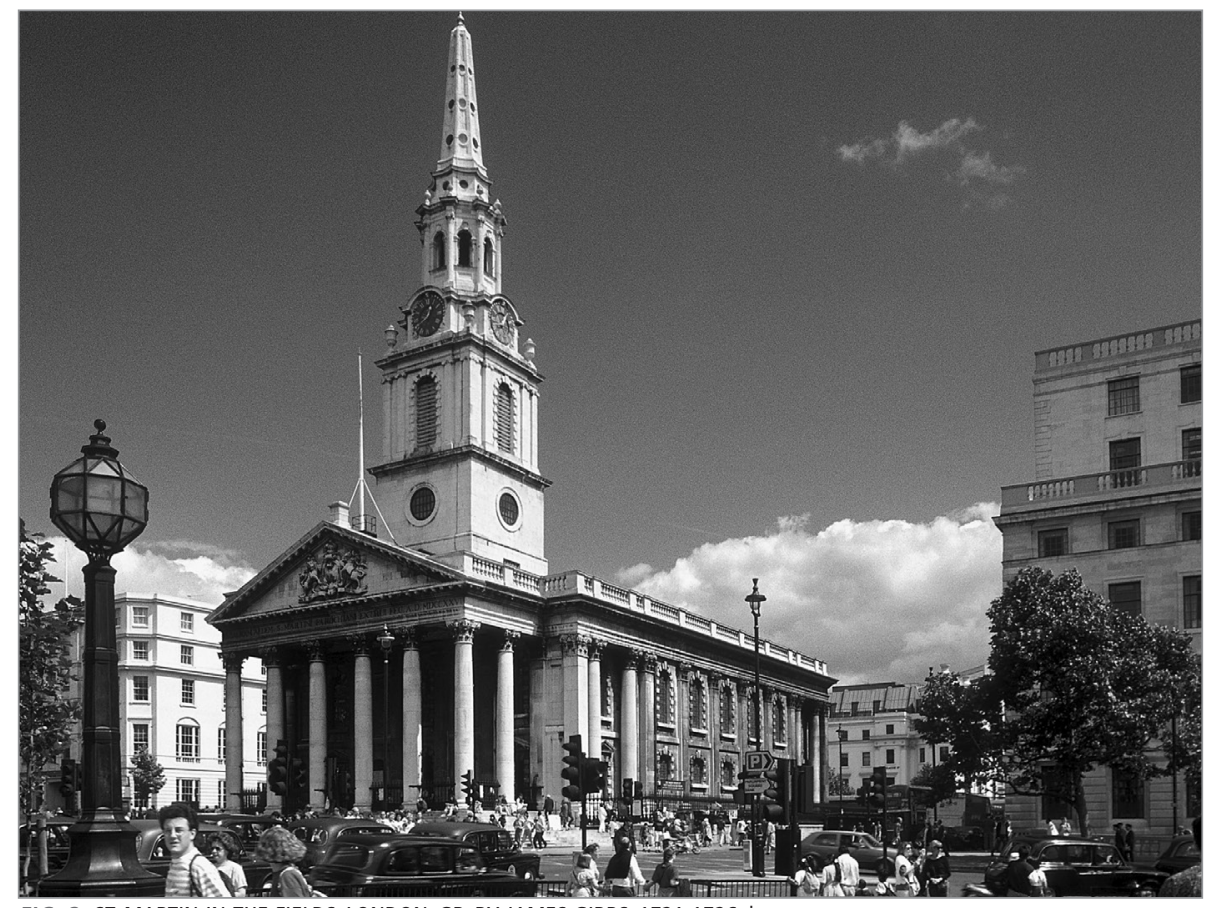

FIG. 2. ST. MARTIN-IN-THE-FIELDS, LONDON, GB, BY JAMES GIBBS, 1721-1726. | PETER COFFMAN.

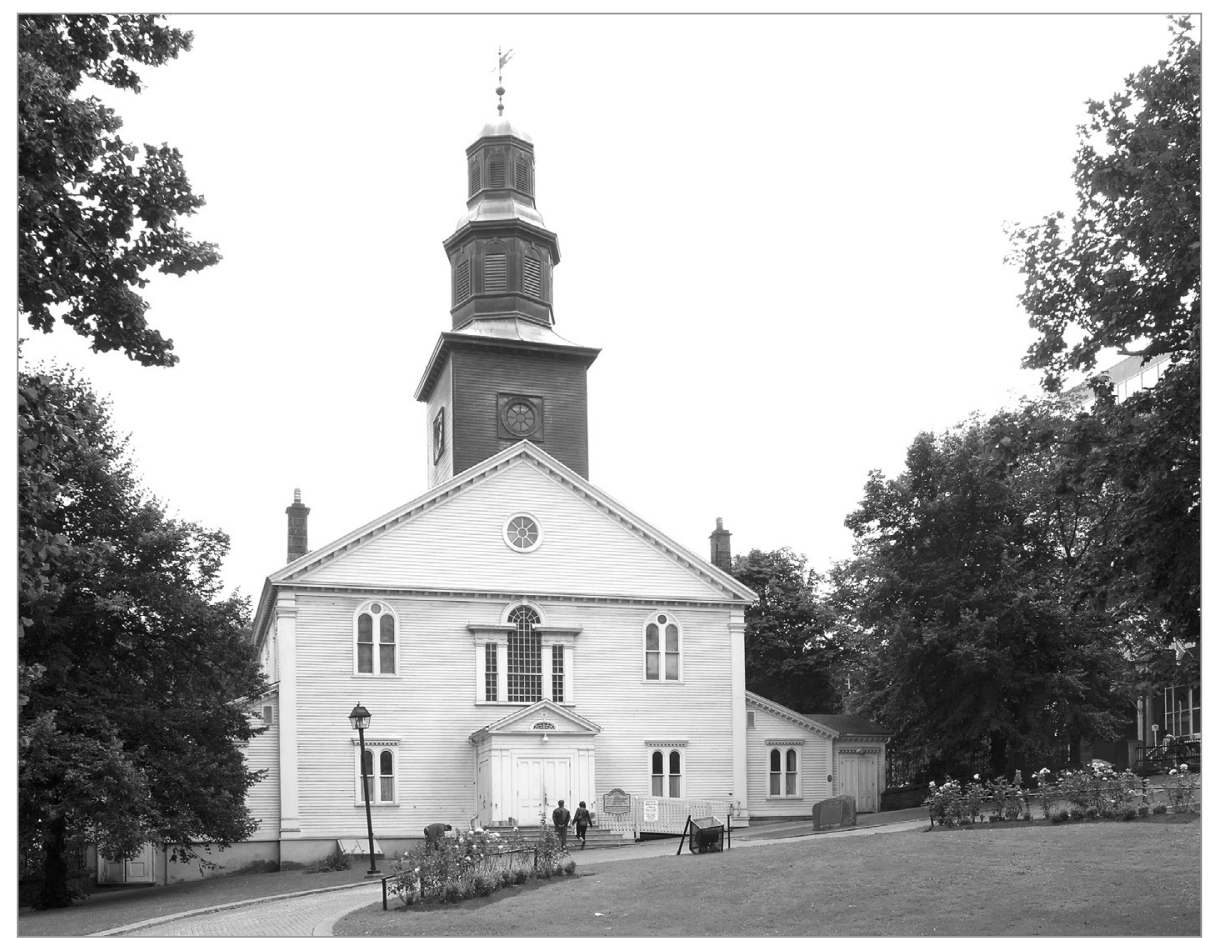

FIG. 3. ST. PAUL'S CHURCH, HALIFAX, NS, BEGUN 1750. | PETER COFFMAN. 


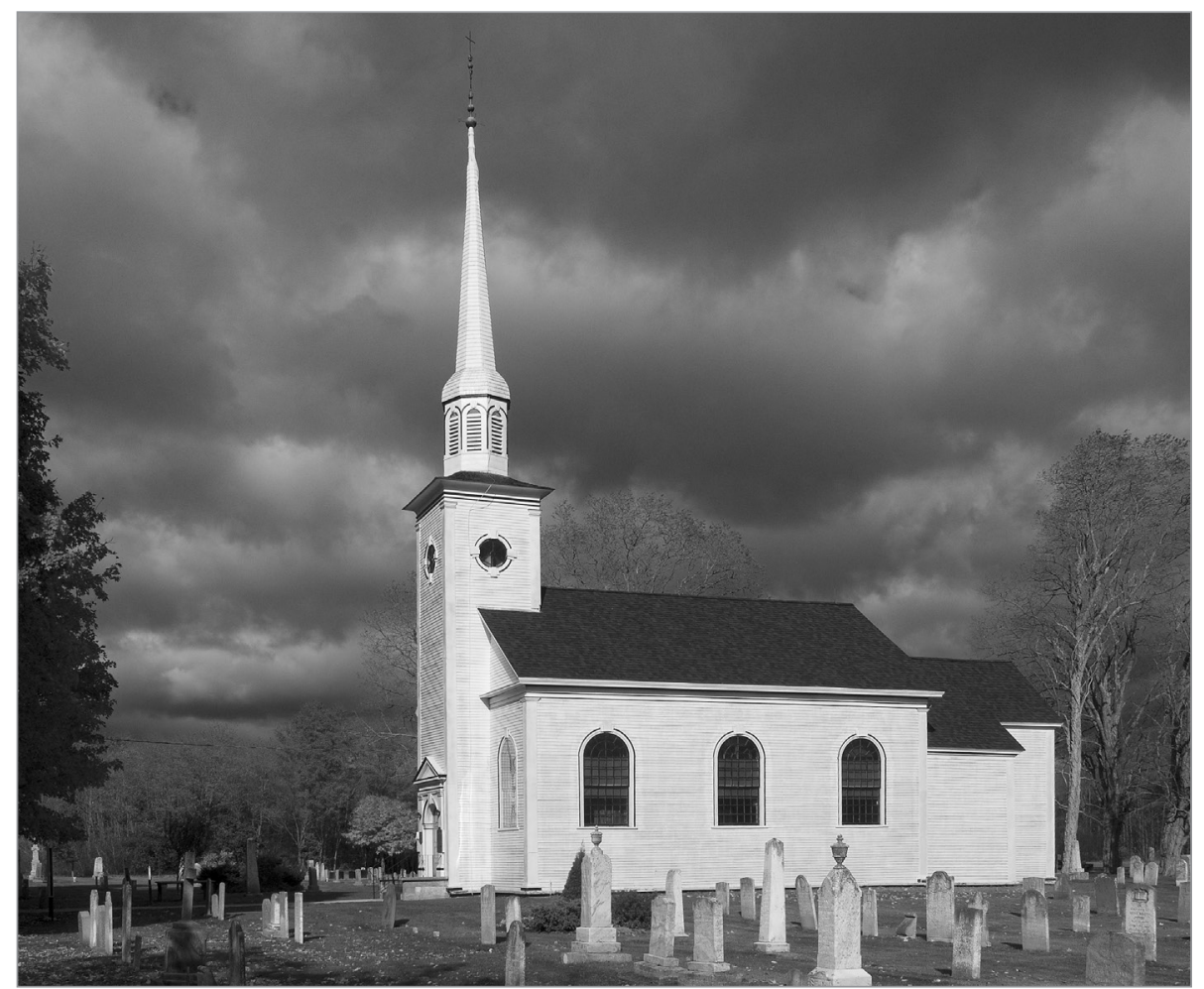

FIG. 4. ST. MARY'S CHURCH, AUBURN, NS, 1790. | PETER COFFMAN.

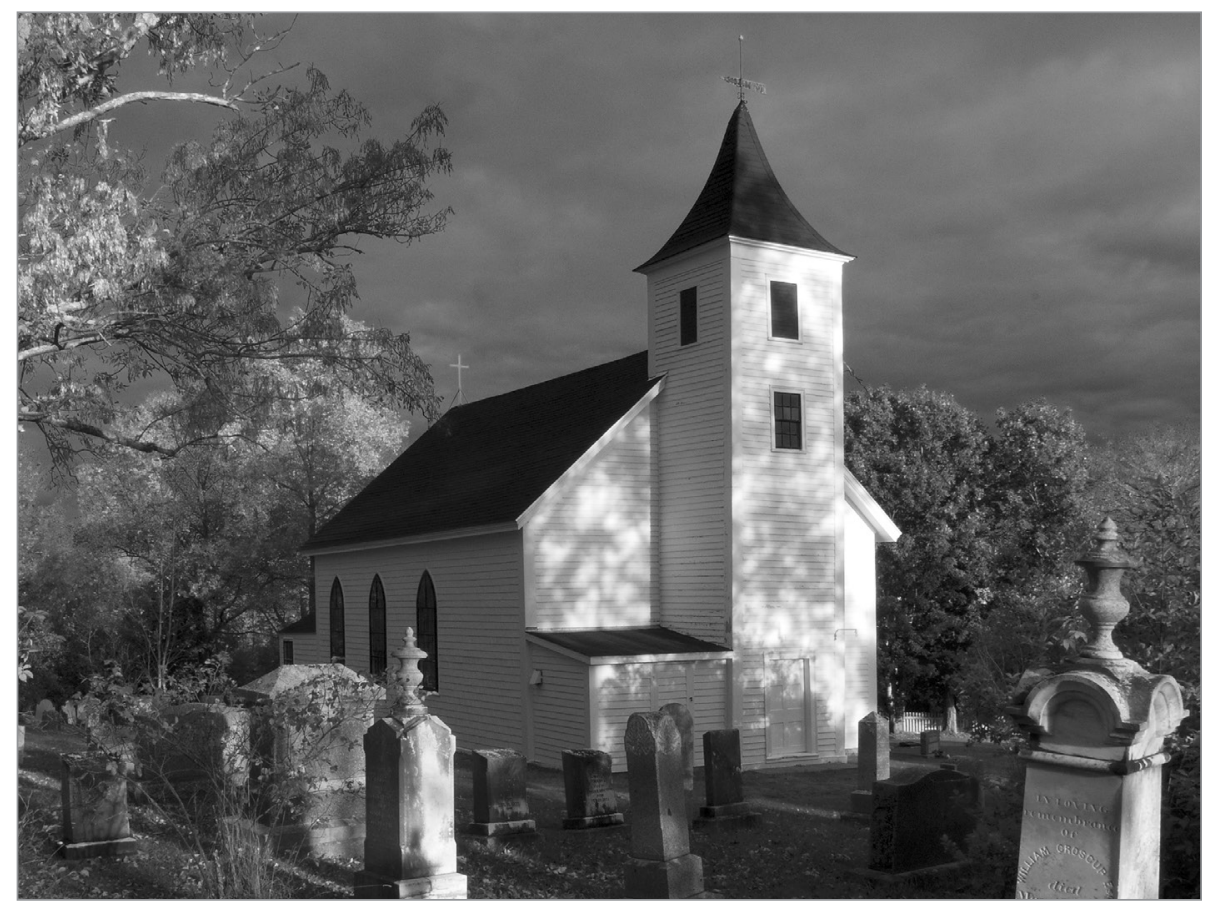

FIG. 5. CHRIST CHURCH, KARSALE, NS, 1791. | PETER COFFMAN. in a letter of 1788, stating: "We are all Loyal American Refugees who have been exiled from the Land of our nativity by means of our firm attachment to both Church and State, and have taken refuge in this place which but five years ago was a thicket of uninhabited woods ... "13

In appealing to Inglis's Loyalist convictions, the settlers of Digby were connecting to a theme that was already well established. A few years earlier, undersecretary of the American Department William Knox had suggested that establishing the Church of England in British North America-that is, making it the official state and state-supported Church of the colony-would be: "the most effective way of excluding Republicans, and drawing the Episcopalians out of the Revolted Colonies into our own, and establishing an everlasting barrier between them."14

In short, the Church was seen by the state as one of the bulwarks against republicanism and revolution, and as a magnet for those of like minds. The churches built as a result of this belief need to be understood not only as places of worship, but as fortresses against seditious and subversive ideas that might drift northward from the former Thirteen Colonies. The first such church in Nova Scotia was St. Paul's in Halifax (1750, fig. 3), ${ }^{15}$ and additional examples survive in the Annapolis Valley: in Auburn (1790, fig. 4), Karsdale (1791, fig. 5), ${ }^{16}$ Middleton (1791, fig. 6), Clementsport (1797, fig. 7), and Cornwallis (1804, fig. 8).

They were an integral part of British North America's strategy for remaining British. These buildings, especially taken as a group, manifest both the anxieties and the aspirations of the Loyalists of the late eighteenth and early nineteenth centuries who settled that area. 
Granville Centre's voice in that collective statement, planted on the landscape two hundred years ago, began to fade early in the twenty-first century. The depleted population of the Annapolis Valley had no need for so many Anglican churches, and All Saints was deconsecrated in 2005. ${ }^{17}$ The Anglican Church decided that the building was surplus, and the firm TimberhArt, based in Hantsport, NS, was hired to find a new home for it. That home turned out to be Louisiana. The building was demolished in the spring of 2010 (fig. 9). After sitting in a Hantsport warehouse for over four years, the timbers of All Saints were shipped to Abita Springs, where they would be born again as a Baptist church.

\section{AN AMERICAN CHURCH?}

But how meaningful a fit could this church be in its new American home? There is no question that the church's new custodian, Pastor Jerel Keene, embraced it unconditionally as a Louisianan Baptist church. As he told the Chronicle Herald, he believed this church was right for him and his congregation from the moment he first saw it advertised online: "I thought, wow, that's what we need. I'm a southern Baptist, a Protestant, and I like the architecture, but I also like that it was tied in to Louisiana through the Acadians." 18

While there can be no doubt of the pastor's enthusiasm for his new acquisition, his historical references raise some complex issues. The question of where the authority to assign meaning to a historic building lies has been contested in recent years. Increasingly, the constructed and contingent nature of heritage value has been recognized, and more emphasis has been placed on the role of the community in constructing meaning. ${ }^{19}$ In particular, the traditional authority of the architectural historian has been challenged, and

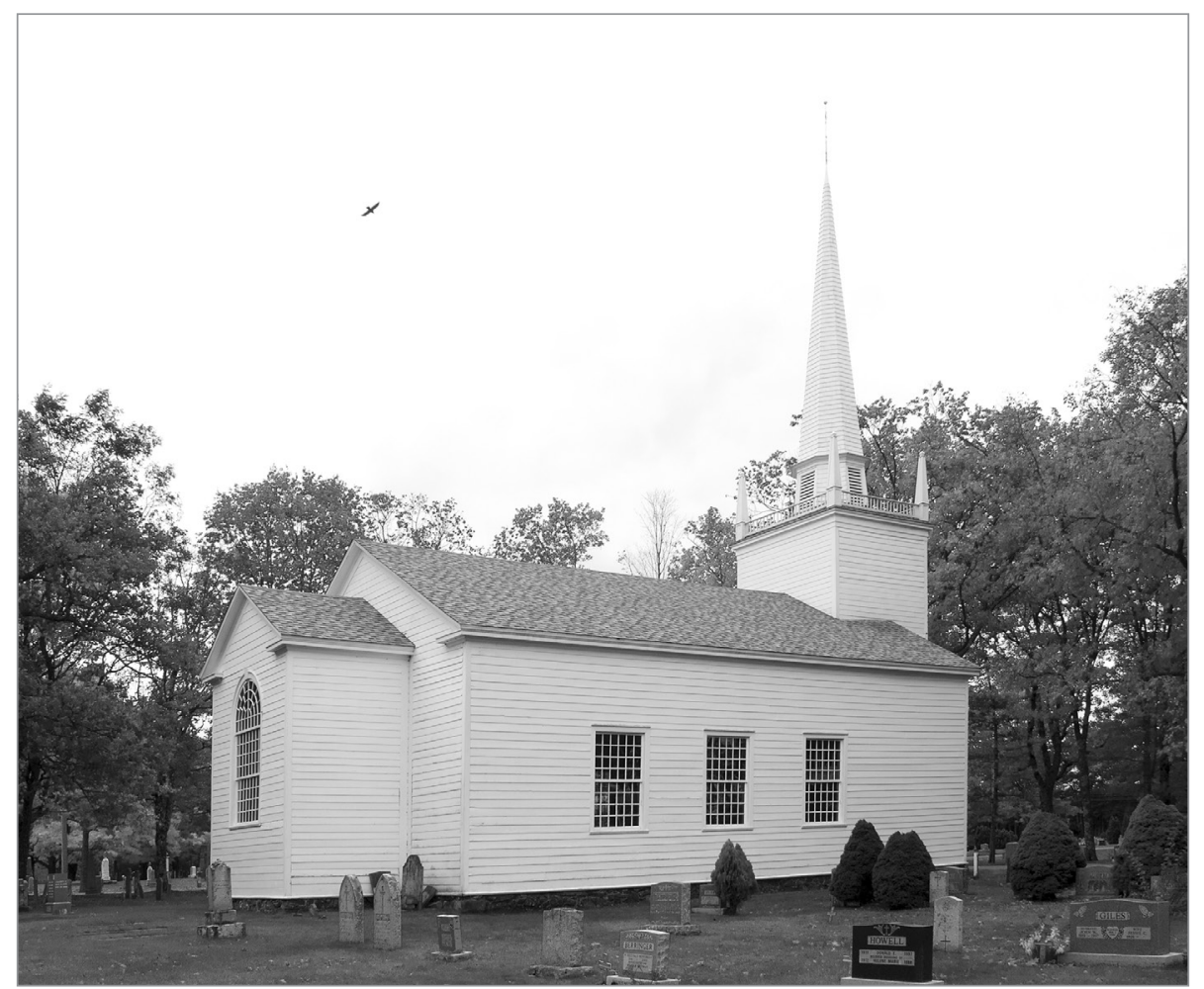

FIG. 6. HOLY TRINITY, MIDDLETON, NS, 1791. | PETER COFFMAN.

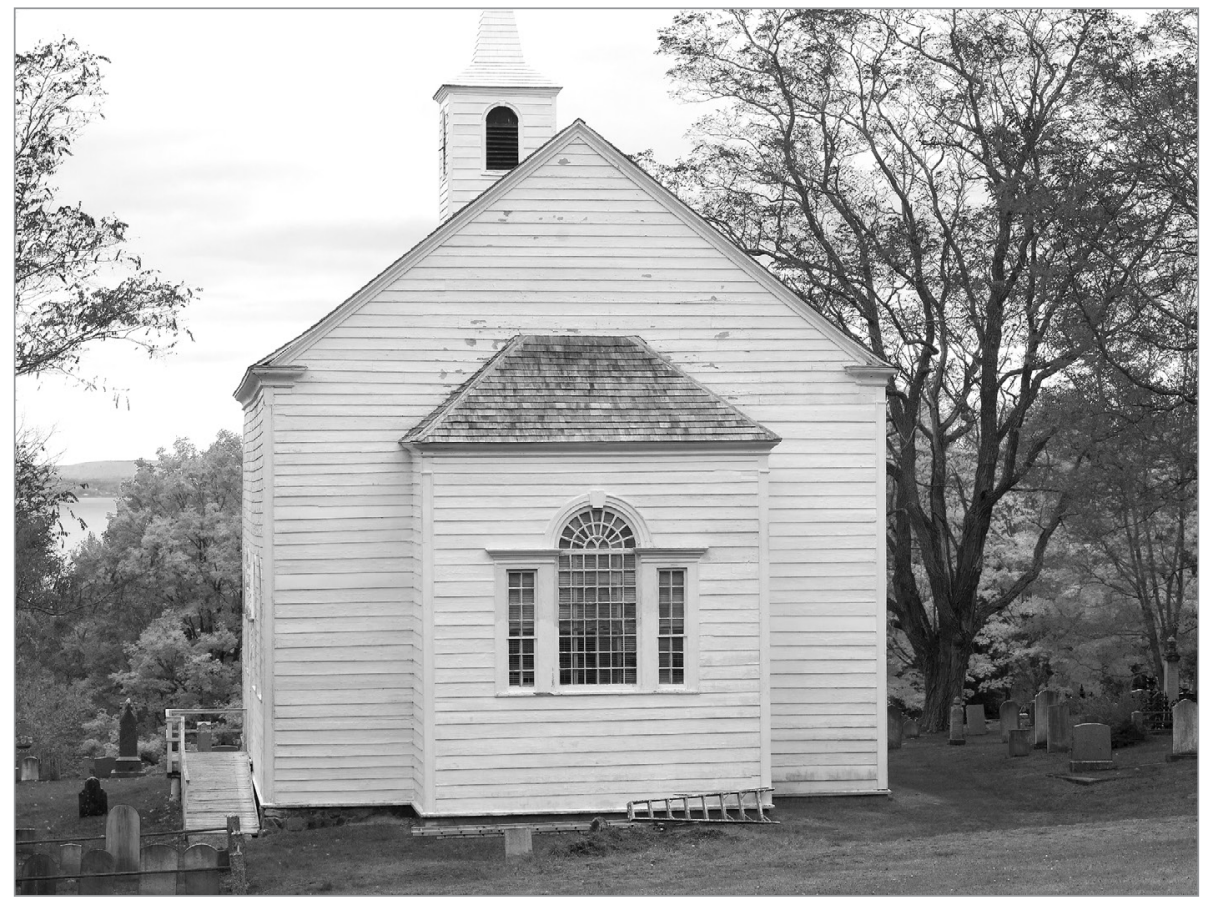

FIG. 7. OLD ST. EDWARD'S, CLEMENTSPORT, NS, 1797. | PETER COFFMAN. 


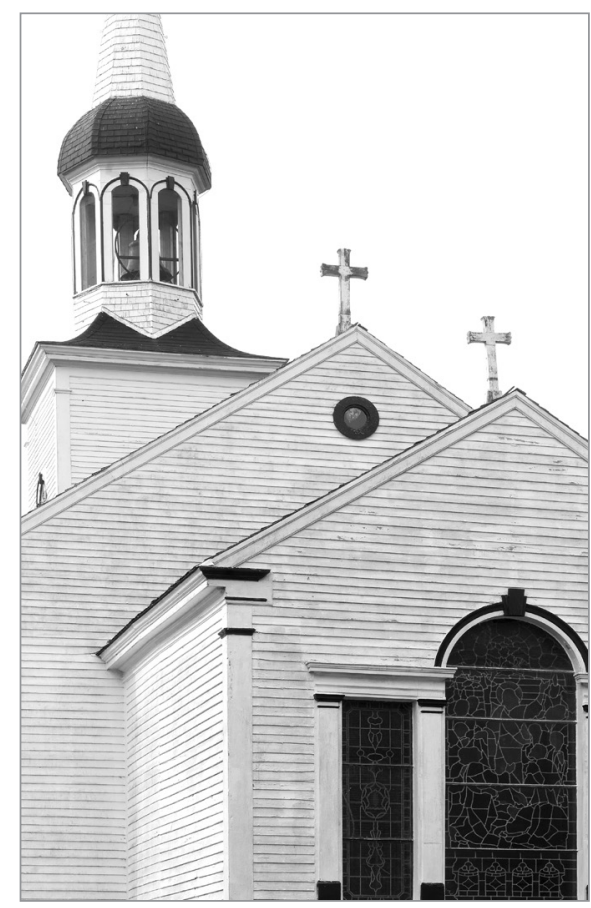

FIG. 8. ST. JOHN'S, CORNWALLIS, NS, 1804. | PETER COFFMAN.

conventional architecturally-based assessments have been replaced with valuesbased criteria.

Nevertheless, if our assessments of heritage value are to be rooted to any degree in historical research, analysis, and fact, then statements like Pastor Keene's need to be challenged. The historical connections he evokes are extremely problematic.

Looking at the first half of the statement, while Pastor Keene is indeed a Southern Baptist, this church emphatically is not. In fact, it was explicitly meant to proclaim rejection of Dissenting faith systems, which represented a world view that Inglis mistrusted deeply. As noted above, in Inglis's view, Dissent was linked to republicanism and revolution. His use of Gibbsian classical detailing and proportions, his west towers, the orientation of his interiors, his insistence on having a

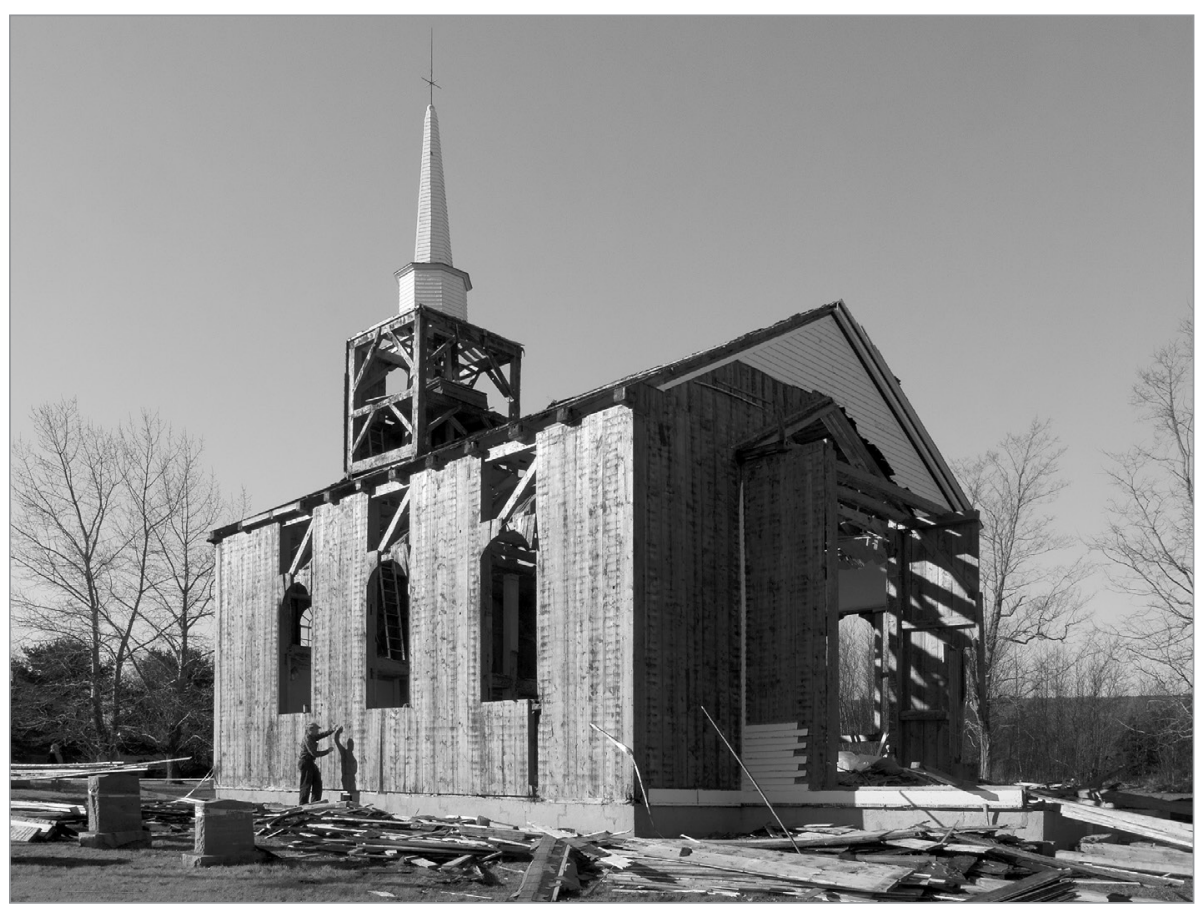

FIG. 9. ALL SAINTS, GRANVILLE CENTRE, NS, DURING DEMOLITION. | PETER COFFMAN.

chancel, all mark his buildings-including All Saints-as emphatically Anglican. Had Pastor Keene and his parishioners realized the pains Inglis took to make sure his churches did not look Baptist, it is possible that they may not have considered this building a good fit.

The alleged historical link to Louisiana via the Acadians is no less problematic. It is true that the Acadian connection to Louisiana is strong, as a substantial portion of the Acadian diaspora ended up there. ${ }^{20}$ There are certainly descendants of Annapolis Valley Acadians in Louisiana. But at the risk of stating the obvious, All Saints is not an Acadian church, nor even a Roman Catholic church, and it does not represent a connection between the Acadian diaspora and their forebears. If the church were to evoke anything at all for descendants of Acadians, it would be the United Empire Loyalists who profited from their ancestors' expulsion after the
Governor appropriated their homeland. As usurpers of their land and beneficiaries of Le Grand Dérangement, the Loyalists are not likely to stir fond memories among Acadians. Built well after the last Acadian had been forced from the Annapolis Valley, All Saints could have no legitimate historical resonance in Louisiana. In short, this building is an alien in Louisiana, conceived in a spirit that was inimical to its current setting and hostile to what its current owners practice and believe. While the case for its "Canadian-ness" may be complex and nuanced, the case against its "Americanness" is anything but.

\section{THE SALE AND DEMOLITION OF ALL SAINTS}

Press coverage (and hence public awareness) of the sale of All Saints did not begin until the deal had been completed. In late 2009 and early 2010, the Canadian 
Broadcasting Corporation (Canada's national broadcaster), The Globe and Mail (a nationally distributed newspaper based in Toronto), and The Chronicle Herald (Halifax's daily broadsheet) all covered the story of the sale and demolition of the church. ${ }^{21}$ In one conversation with the $C B C$ 's Colleen Jones, and in personal communication with me, the president of the Annapolis Heritage Society, Ryan Scranton, revealed that the Society had offered to purchase All Saints from the Anglican Church and maintain it, in situ, in perpetuity (fig. 10). Based on subsequent comments by Canon Ken Vaughan, who had overseen the sale on behalf of the Church, Scranton estimated that the Annapolis Heritage Society's offer had at least matched, and likely exceeded the offer from Louisiana. ${ }^{22}$ Fairly or not, the Church's complete disinterest in this offer suggested a lack of transparency that fuelled an increasingly antagonistic relationship between the heritage community and the Church.

This adversarial relationship was escalated by some of the misinformation that was circulated. Canon Ken Vaughan (fig. 11, shown with the CBC's Colleen Jones) framed the sale of the church as a veritable act of Christian charity in the Chronicle Herald: "We were told by the contractor that it's going to replace a building that was destroyed by Katrina in the southern United States. We're really delighted about that. It's going someplace where it's needed." 23

Hurricane Katrina had devastated parts of Louisiana, especially New Orleans, in the late summer of 2005. With the dead numbering well over one thousand and economic impact well into the billions of dollars, ${ }^{24}$ Katrina was a humanitarian disaster of immense proportions. Given the sheer scale and intensity of suffering in its aftermath, begrudging its victims

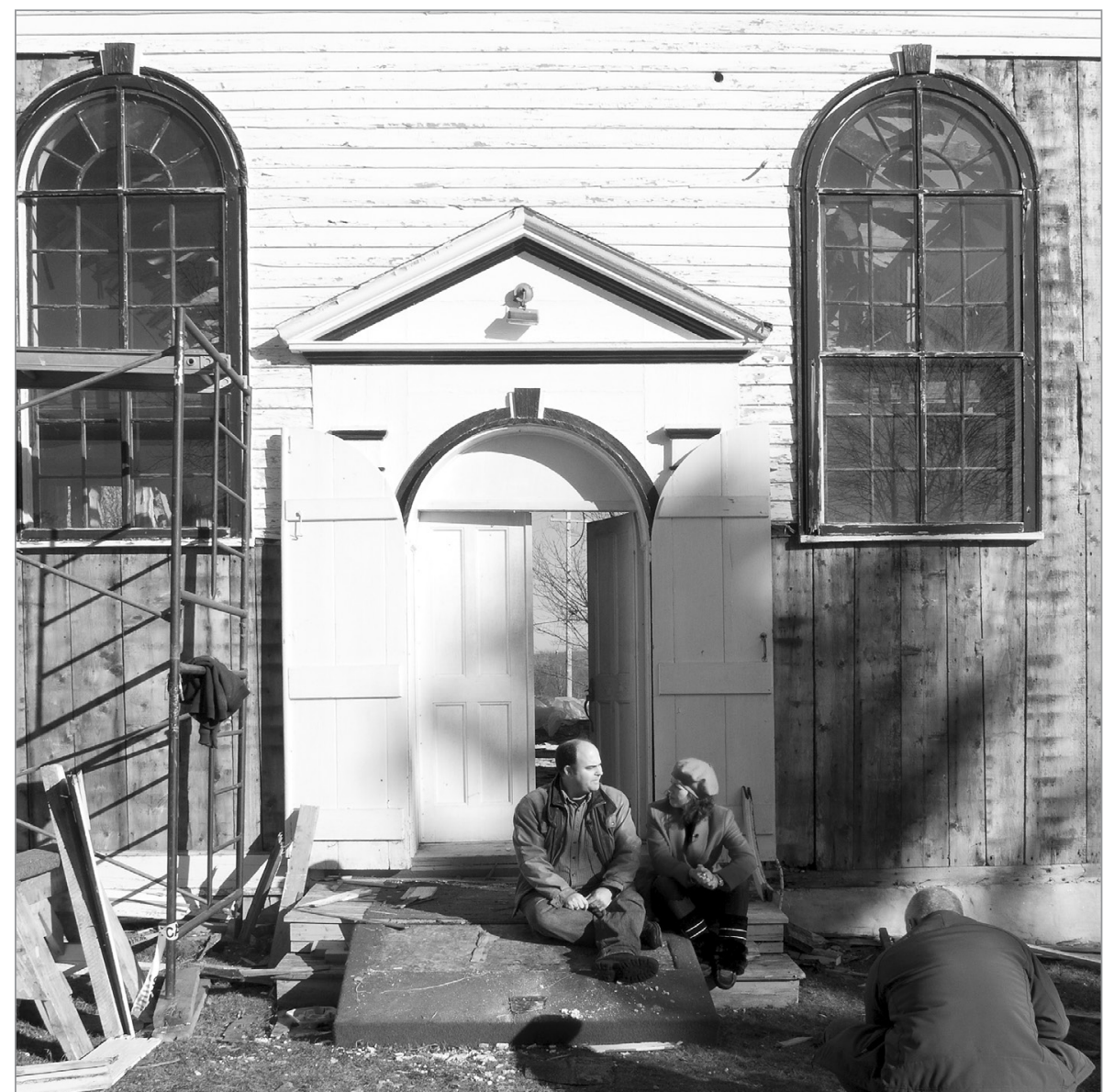

FIG. 10. RYAN SCRANTON AND COLLEEN JONES WITH A CBC CAMERA OPERATOR AT ALL SAINTS, GRANVILLE CENTRE, DURING THE DEMOLITION IN 2009. | PETER COFFMAN.

a redundant church from the Annapolis Valley would seem to be an act of singular selfishness.

Unfortunately, the story was untrue. The rather more pedestrian reality was discovered by Gordon Delaney, a reporter for the Chronicle Herald, and conveyed as the demolition of the church was taking place: "Mr. Keene said his congregation is new and recently built a Christian daycare centre on Main Street in Abita Springs, which has a historic downtown area. Rather than build a new church and make it look old, the congregation focused on finding an old church and rebuilding it." 25
Whether the Katrina story was cynically disingenuous or the result of an innocent misunderstanding is perhaps less important than the fact that another plank in the argument in favour of moving the building from the Annapolis Valley had dissolved. It was not an affirmation of Acadian presence in Louisiana, nor was it an act of charity toward hurricane victims. Unsurprisingly, common ground between the Church and heritage advocates became increasingly difficult to find as events continued to unfold.

Given the nineteenth-century roots of the building being argued over, it 
was perhaps appropriate that one of the battlegrounds was the letters-tothe-editor pages of a national daily newspaper, the Globe and Mail. One supporter of the sale, a Ms. Wilson, made this case: "The Anglican Church is a community of the faithful, not a community of buildings. Its history is one of deep and abiding grace. Grace enough to gift this beautiful empty building of its past to a congregation with a future. One that will once again fill its spaces with song and praise." 26

As an architectural historian growingly concerned with what seemed to me a disregard by the defenders of the sale for historical reality, I wrote a reply to Ms. Wilson which was printed in the Globe and Mail the following day:

To interpret the sale of our history and heritage as an act of grace seems to me optimistic in the extreme. But since the original claim that the church would replace one lost to Hurricane Katrina proved false, and as the subsequent claim that the church was connected to Louisiana through the Acadians proved ridiculous, it's apparently the last line of defence. ${ }^{27}$

Whichever position one takes on the issue, it is important to note the fundamentally different premises of these letters. The first writer assumes that the meaning and value of the building reside wholly in the ritual performed within. The second letter assumes that the very fabric of a building, once one knows how to read it, contains cultural information and historical narratives that make it a uniquely compelling, experiential historical document. If it were still sitting in Granville Centre, All Saints might be empty of ritual but it would remain full of meaning and historical echoes. In Abita Springs, it is a novelty act and an imposter.

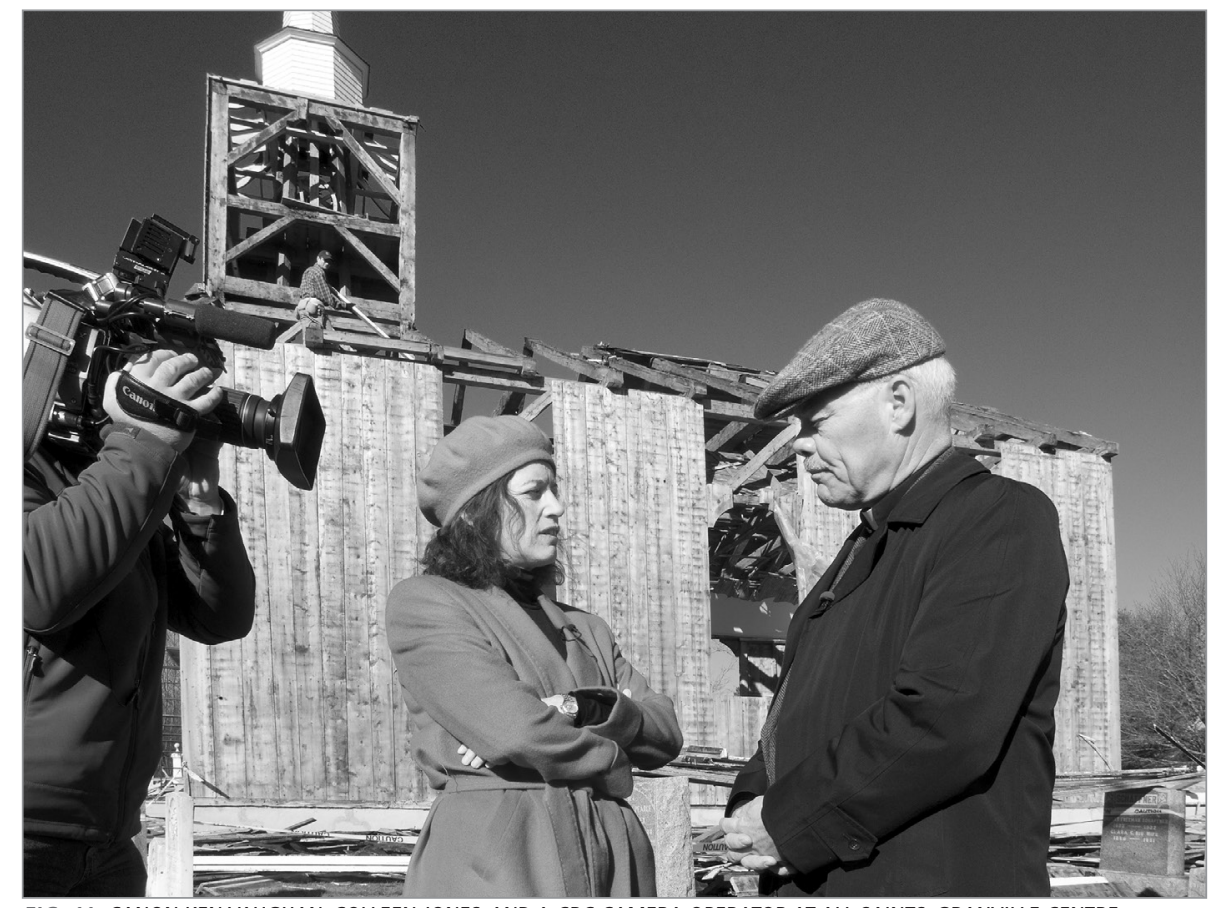

FIG. 11. CANON KEN VAUGHAN, COLLEEN JONES, AND A CBC CAMERA OPERATOR AT ALL SAINTS, GRANVILLE CENTRE, DURING THE DEMOLITION IN 2009. | PETER COFFMAN.

The gulf between the two sides was widened by the fact that not only were there no agreed-upon facts on which to base an assessment of the historic importance of All Saints, but there did not appear to be universal agreement that such facts were relevant. Canon Vaughan claimed in the Chronicle Herald that only Christ Church in Karsdale had significant heritage value for the Church in the Annapolis Valley: "That's the oldest of the buildings in the parish. It really is the heritage site in this part of the world." ${ }^{28}$ No evidence or argument was given for that claim, nor for the notion that "this part of the world" could have only one heritage site. Presumably the fact Christ Church was begun roughly twenty years before All Saints was thought to make it selfevident. Like the specious connection with the Acadians discussed above, and the discredited connection with more recent events surrounding Hurricane
Katrina, history was being invoked to support the argument for moving the church to Louisiana. But when invoking history to prove a point, getting that history right is important. And in getting history right, facts matter. ${ }^{29}$ That this tempest in a heritage teapot is a microcosm of our current broader political discourse scarcely needs pointing out.

\section{EPILOGUE}

In March of 2015, CBC News ran a story reporting that the re-construction of All Saints was nearing completion. ${ }^{30}$ According to the article, the plaster walls and exterior cladding did not survive the move. One of the windows is now obscured by an air conditioning duct, made necessary by the Louisiana climate. The original chancel window will eventually be put back in place, but the conversion of the chancel into a baptistery 


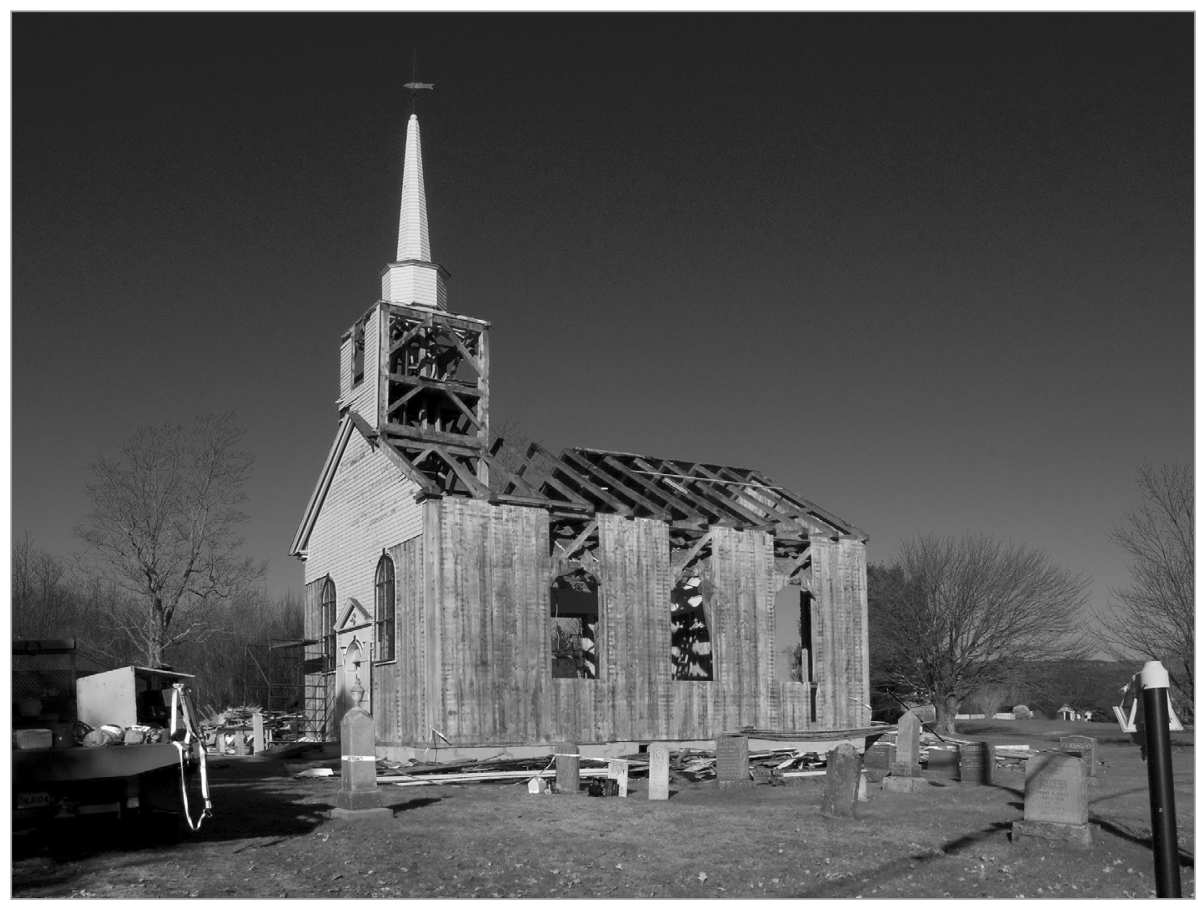

FIG. 12. ALL SAINTS, GRANVILLE CENTRE, IN THE AUTUMN OF 2009. | Peter COFFMAN.

with a large, elevated platform means it will not be visible from the inside of the church.

Is that a happy ending? Without a doubt, it is far better than demolition. Nevertheless, demolition was not the only other option for All Saints. It is a commonplace heritage reality that if we try to save everything, we will end up saving nothing. That said, there was a concrete opportunity to save All Saints; what was lacking was the will to do so. The apparent ease with which this historic building was lost serves as an ominous reminder of a statement once made by the Canadian literary critic Northrop Frye: "when you lose your memory you become senile, and that's just as true of a society as it is of an individual." 31 It is to be hoped the early twenty-first century will not be remembered as the age that rushed blithely toward its own senility.

\section{NOTES}

1. I would like to thank Malcolm Thurlby, guest editor of this volume, and Jessica Mace, editor in chief of the JSSAC, for their fine work and patience. I am grateful to George Cooper, who first alerted me to the sale of All Saints, and to Ryan Scranton, former president of the Annapolis Heritage Society, for his insights into the sale process. For assistance with this research and the larger project of which it forms a part, I would like to thank Lorraine Slopek of the Diocesan Archives of Nova Scotia, Garry Shutlak of the Provincial Archives of Nova Scotia, and Shirley Tillotson and Claire Campbell of Dalhousie University. The first iteration of this paper was in a session of the SSAC Conference in Annapolis Royal, chaired by Candace Iron.

2. On Charles Inglis, see Vanderbilt Harris, Reginald, 1937, Charles Inglis: Missionary, Loyalist, Bishop (1734-1816), Toronto, ON, General Board of Religious Education; Fingard, Judith, 1968, "Bishop Inglis and his 'Primitive Bishoprick' in Nova Scotia," Canadian Historical Review, vol. 49, no. 3, p. 247-266; and Cuthbertson, Brian, 1987, The First Bishop: A Biography of Charles Inglis, Halifax, NS, Waegwoltic Press.
3. On Gibbs, Summerson, John, 1983, Architecture in Britain 1530-1830, Harmondsworth, Penguin Books, p. 129-142. On his influence in Loyalist Nova Scotia, see Coffman, Peter, 2014, "The Gibbsian Tradition in Nova Scotia," in Matthew M. Reeve (ed.), Tributes to Pierre du Prey: Architecture and the Classical Tradition, from Pliny to Posterity London/Turnhout, Harvey Miller Publishers, p. 211217.

4. On Church of England Loyalists in Nova Scotia, see Fingard, Judith, 1972, The Anglican Design in Loyalist Nova Scotia 1783-1816, London, SPCK (Society for Promoting Christian Knowledge).

5. Delaney, Gordon, 2009, "Venerable Valley Church Moving to Louisiana," The Chronicle Herald, November 17.

6. Kalman, Harold, 1994, A History of Canadian Architecture, Toronto, Oxford University Press.

7. On the history of the Acadians, see Laxer, James, 2006, The Acadians: in Search of a Homeland, Toronto, Doubleday Canada.

8. Noppen, Luc, 2006-2007, "L'église SainteMarie, monument du métissage de modèles bretons et de savoir-faire acadiens," Port Acadie, Revue interdisciplinaire en études acadiennes, special issues guest-edited by Jean-Pierre Pichette: Le patrimoine religieux de la Nouvelle-Écosse. Signes et paradoxes en Acadie, vols. 10-11-12, p. 117128.

9. Summerson, Architecture in Britain, p. 352.

10. Coffman, "The Gibbsian Tradition in Nova Scotia," op. cit.

11. Vestry Record for the Parish of Granville Commencing September 29, 1806, Diocesan Archives of Nova Scotia, MG3 $3^{\text {rd }}$ Series, vol. 15 no. 3. See also Duffus, Allan, G. Edward MacFarlane, Elizabeth Pacey, and George W. Rogers, 1982, Thy Dwellings Fair: Churches of Nova Scotia 1750-1830, Hantsport, NS, Lancelot Press.

12. Gowans, Alan, 1966, Building Canada: An Architectural History of Canadian Life Toronto, University of Toronto Press. See also Thomas, Christopher, 1997, "'Canadian Castles'? The Question of National Styles in Architecture Revisited," Journal of Canadian Studies, vol. 32, no. 1, p. 527.

13. Book of Proceedings of the Church Wardens and Vestry in the Town of Digby Commencing the $29^{\text {th }}$ Day of September 1785, Diocesan Archives of Nova Scotia, MG3, $3^{\text {rd }}$ Series, vol. 13 , no. 4 , p. 43.

14. Fingard, The Anglican Design, p. 3. 
15. On St. Paul's Church, see McAleer, J. Philip, 1993, A Pictorial History of St. Paul's Anglican Church, Halifax, Nova Scotia, Halifax, NS, Technical University of Nova Scotia; McAleer, J. Philip, 1984, "St. Paul's, Halifax, Nova Scotia, and St. Peter, Vere Street, London, England," The Journal of Canadian Art History, vol. 7, no. 2, p. 113-137; Tuck, Robert, 2004, Churches of Nova Scotia, Toronto, ON, Dundurn Group, p. 13-20; Harris, Reginald V., 1949, The Church of St. Paul in Halifax, Nova Scotia: 1749-1949, Toronto, ON, Ryerson Press; Duffus et al., Thy Dwellings Fair, op. cit.

16. Christ Church in Karsdale, while essentially Gibbsian in configuration, also has the distinction of having Gothic windows of 1791. It and Middleton, finished around the same time, might mark first appearance of Gothic Revival features in Canada. See Coffman, "The Gibbsian Tradition in Nova Scotia," p. 219.

17. Hoare, Eve, 2014, "N.S. Anglican Church Relocated to Louisiana," The Chronicle Herald, January 2.

18. Delaney, Gordon, 2009, "Louisiana Pastor Excited about New-to-him Church," The Chronicle Herald, November 21.

19. For a discussion of this in a Canadian context see Barrett, Scott and Patrice Dutil, 2012, "Social Learning, Feedback Loops, and Public Spheres: Implementing a Valuesbased Management Model in Heritage Conservation," Journal of the Society for the Study of Architecture in Canada, vol. 37, no. 1 p. 1726.

20. For a discussion of the Acadian diaspora, see Laxer, The Acadians, op. cit.

21. In addition to articles already cited, see Coffman, Peter, 2010, "It's Time to Talk about Protecting our Past," The Chronicle Herald, January 27
22. Personal communication with Ryan Scranton, November 2009.

23. Delaney, Gordon, "Venerable Valley Church Moving on to Louisiana," op. cit.

24. Louisiana Geological Survey, 2006, Geology and Hurricane - Protection Strategies in the Greater New Orleans Area, Public Information Series no. 11, summer.

25. Delaney, "Louisiana Pastor Excited about Newto-him Church," op. cit.

26. Wilson, Simone, 2009, "When the Saints Go Marching in," The Globe and Mail, December 21.

27. Coffman, Peter, 2009, "Saints Preserve Us," The Globe and Mail, December 22.

28. Delaney, "Venerable Valley Church Moving to Louisiana," op. cit.

29. For a penetrating analysis of the manipulation of history, see MacMillan, Margaret, 2008, The Uses and Abuses of History, Toronto, Viking.

30. Rhodes, Blair, 2015, "All Saints Anglican Church resurrected in Louisiana," CBC News, March 17, [http://www.cbc.ca/news/canada/ nova-scotia/all-saints-anglican-church-resurrected-in-louisiana-1.2997306], accessed April 1, 2018

31. "The Ideas of Northrop Frye," interview transcript by David Caley, 1990, [http:// www.davidcayley.com/transcripts/], part 3, p. 25: [https://static1.squarespace.com/ static/542c2af8e4b00b7cfca08972/t/58ff b8029f74569223d6db63/1493153830839/ Ideas+Northrop+Frye_3.pdf], accessed May 30, 2018. 